\title{
OWNERSHIP CONCENTRATION AND FIRM PERFORMANCE DURING GLOBAL FINANCIAL CRISIS: EVIDENCES FROM INDIA
}

\author{
Harendra Nath Tiwari \\ Assistant Professor, Shri Ram College of Commerce, New Delhi, India \\ Dr. Hem Chand Jain \\ Officiating Principal \&Associate Professor, Deen Dayal Upadhyaya College, New Delhi, India
}

\begin{abstract}
In this paper we examine the relationship between ownership concentration and firm performance global financial crisis. Ownership concentration has been researched extensively; however, there have been various gaps in the research landscape under the same umbrella term. Relationship of various variables under different scenarios and contexts can be checked with ownership concentration to ascertain its effect on firm performance - the sub-prime context is one of them. The firm performance has been measured taking into consideration the risk, the returns and risk-adjusted return. Panel data analysis has been applied on data of 1256 firms from 2007 to 2016. The ownership concentration shows a positive impact on stock return and risk-adjusted return and negative impact on the risk profile of the firm. This shows a positive impact of ownership concentration on firm performance. Such relationship between ownership concentration and firm performance is observed to be stronger during the period of global financial crisis. These results serve to present a contribution in an otherwise lesser tapped area of study in relation to ownership concentration and firm value. The findings aim to help investors, both big and small, and other stakeholders of the financial ecosystem to make decisions as to where to invest when a crisis is foreseen or is ongoing.
\end{abstract}

Key words: Global financial crisis, panel data, Indian firms, ownership concentration, firm performance.

Cite this Article: Harendra Nath Tiwari and Hem Chand Jain, Ownership Concentration and Firm Performance during Global Financial Crisis: Evidences from India, International Journal of Management, 11(12), 2020, pp. 2788-2799.

http://iaeme.com/Home/issue/IJM?Volume=11\&Issue=12

\section{INTRODUCTION}

Corporate governance is instrumental in a firm's sustained financial performance. It results in lower cost of capital, higher returns on equity, greater efficiency, and more favorable treatment 
of all stakeholders(Claessens, 2006). Thus changing the way a firm is governed, there is a substantial scope of improving financial performance of the firm and making contributions to the market and the country. The governance of the firm largely depends upon the institutional setup within which the firms operate as well as on the concentration of ownership. Indian firms are characterized by concentrated ownership in the hands of the managers largely owned by families. In family owned firms there is hardly any distinction between the owners and managers and, therefore, delays in decision making process are generally not observed(Salim, 2005).

Previous studies on ownership concentration are of the view that owner-controlled firms are more profitable than the manager-controlled firms as owners offer better monitoring and it assures the suppliers of the funds that they will get return on their investment(Shleifer \& Vishny, 1997). "Ownership represents a source of power that can be used either to support or oppose management, depending on how it is concentrated and used. In general, the more concentrated ownership is the more potent potential support or opposition" (Salancik \& Pfeffer, 1980). An incorrect split of ownership concentration with respect to the domain and competitive landscape of the firm can lead to major organizational disasters, financially and otherwise.

Ownership concentration, recruitment policies, board composition, competitive landscape and global presence are some of the factors guiding the performance of a firm. A firm might have all these factors working well for them in the regular course of business but how these factors respond in the situation of crisis can make or break a firm. Crises are often associated with huge financial losses and instability in the human resource pool due to lay-offs, delayed payment of salaries or wages and general distrust among the workforce. Not only do the resources get affected negatively, but the goodwill of the company and the stakeholders get tarnished as well. The whole set of tangible and intangible factors in and around the firm change during crises. However, the firms that are able to return premium to their shareholders better manage the market competition and they are able to survive the economic crisis periods(Saleh et al., 2017). South Asian firms, especially Indian firms, are mostly family owned. There is no real separation of ownership and management enabling the firms to have a swift decision making process which becomes more significant during the times of economic downturns. A study by (Leung \& Horwitz, 2010) found that Hong Kong firms with highly concentrated management ownership performed better in capital market during thirteen months of the Asian financial crisis.

During financial downturns, equity investment is a great concern for the large investors.It leaves a situation in the hands of the shareholders to either make the best out of the situation by finding an opportunity and capitalizing on it or just pull out their money and leave the firm hanging in this situation. On the other side, how the management deals with a crisis also depends upon the concentration of power and how decisionsare implemented by the managers at different management levels - a major trade-off being the speed of decision-making versus the comprehensive inputs of the employees. Crises call for spontaneity and rationality. The urgency calls for quick decision making and that leaves little to no scope for running a decision through the whole chain of command/hierarchy. For example, in the recent times involving a major crisis situation due to the global pandemic caused by the COVID-19 or Coronavirus outbreak, a large set of people explained how China could manage to protect or prevent more than $75 \%$ of the caused damage if it could take appropriate decisions almost 10 days before it actually took those decisions. This argument was also backed up by a leading epidemiologist who was also an expert member of the medical panel dispatched by the central government to the epicenter Wuhan.

Despite extensive literature available examining the relationship between ownership concentration and firm performance (Jensen \& Meckling, 1976; Shleifer \& Vishny, 
1986;Edgerton, 2012 and others), the review of literature points out that there are still many conceptual and empirical gaps that need to be analyzed in the context of the relationship between ownership concentration and firm performance. Also, there is not enough literature available examining how does family owned firms perform in capital market during a financial crisis, especially in the context of Indian firms. Global Financial Crisis (GFC) 2007-08 caused rapid decrease in trade of goods and services world over. India was also not spared. The stock market witnessed a great downfall. Considering all these, we felt a need for exploring the impact of concentrated ownership on firm performance in stock market by Indian firms. In the present empirical research paper we have investigated the impact of concentrated ownership in determining the return, risk and risk adjusted return of Indian firms, especially during Global Financial Crisis. Our paper contributes to the existing literature by providing evidence of the impact of ownership concentration on the firm performance in the Indian context.

\section{FINANCIAL CRISIS AND ITS RELEVANCE}

The world witnessed one of the major crises around 1929-33 - the Great Depression. It was the most severe and the longest crisis ever experienced by the western world. Although it originated in the USA, it affected almost every other country leading to decreased output, massive unemployment and acute deflation. In the fall of 1930s, the Wall Street had already crashed, banks failed and people were deep into debt. By 1933, unemployment was at $25 \%$ and more than 5000 banks had gone out of business. This whole scenario changed the whole structure of how the businesses are brought about a lot of new regulations and changes in corporate governance.

In October 1987, the US markets witnessed the largest one-day percentage drop in the stock market - the Dow Jones Industrial Average dropped by 508 points which is almost a $22 \%$ drop. Worldwide losses faced by 23 major markets were estimated close to $\$ 1.7$ trillion.

India faced a major economic crisis in 1991 because of currency overvaluation, the current account deficit and a sharp forex rate decline. The Indian industries were entering a vicious cycle of scarcity, control and low productivity. In the early 1990s the world felt a global recession. Countries like New Zeeland, Mexico were among the ones whose economies were hit the hardest while Sweden and Finland faced a banking crisis during this period.

The Asian financial crisis started on July 1997. The crisis began with Thailand due to its increasing debt but Indonesia was hit the hardest. The rupiah devalued and the Jakarta Stock exchange touched its historic low in September. By the end of December of 1997, the stock market fell by $49 \%$, the unemployment increased to $13.2 \%$ and the economy dropped by $15 \%$.

In 2008, the worst ever financial crisis since the Great Depression was experienced by the global economy. This subprime crisis cost the US around $\$ 648$ billion and its ripple effects were seen all over the world. With a major impact on the stock values, many people lost their jobs and saw a reduction in wages. In India, growth and exports fell sharply after the crisis; the GDP declined to $5.8 \%$ from the preceding growth rate of $11 \%$.

However, it is not that the crisis always negatively affects everyone. During Asian financial crisis, the Hong Kong firms with concentrated management in the hands of managers did well in capital market. According to Dow Jones Market Data, the S\&P gained 14.59\% after the first occurrence of SARS (Severe Acute Respiratory Syndrome). Even during the Covid-19 period the world economy is contracting but the capital markets are flourishing. In the financial year 2019-20, Indian economy is expected to fall with a negative growth rate of 7.7 percent while the Indian stock market (BSE Sensex) is about to touch 50000 mark. Although the US economy has shown significant decline in GDP due to Covid-19, the market capitalization of stocks increased by US $\$ 584$ billion during the period of March 2020 to June 2020. 
All of these crises proved that it is not guaranteed that the firms which have been performing well will continue to do so even in the face of a crisis. Before making a final conclusion one has to factor in the factors like ownership concentration, nature of business and the effectiveness of the decisions taken by top management. The policy decisions taken by top management is always an important factor affecting the firms' performance, however, it becomes more critical during crisis period. The timing of a decision; the intensity of the consequences; the magnitude of the resources utilized and the way the retaliation is handled by the firms in times of a crisis largely affects the success or failure of the firm. The ownership structure is a significant determinant affecting the decision making process. Therefore, we aim to explore and establish the relationship between the ownership concentration and performance of Indian firms in the capital market, especially during Global Financial Crisis.

\section{THEORIES/ARGUMENTS RELATING TO OWNERSHIP CONCENTRATION}

In order to have a better understanding of the relationship between ownership concentration and firm performance it is extremely important to understand the theoretical support the literature provides and the arguments presented by various schools of thoughts. We have made a humble attempt to present an unbiased compilation of the arguments that revolve around ownership concentration to weigh the opposite schools of thoughts equally.

\subsection{Arguments in Favour of Ownership Concentration}

\subsubsection{Monitoring Argument}

According to monitoring argument of ownership, large shareholders can better monitor and control the managerial activities resulting in better contribution to corporate performance, market and the country (Shleifer \& Vishny, 1986). Further, Grossman and Hart (1982) points out that if ownership is widely dispersed, no shareholder will have the incentive to monitor the managers. Therefore, shareholders owning a large share of the firms' equity have more incentives to monitor management because they may be more affected by the actions of management and partly benefiting more from their own monitoring effort than the shareholders owning just a little share of the firms' equity(Grossman \& Hart, 1986; Huddart, 1993; Shleifer \& Vishny, 2007).Ownership concentration makes it easier for the bulk shareholders to monitor the management and helps in reducing the possibility of conflict of interests. This not only makes the monitoring efficient and speedy but also reduces agency cost, especially in the times of a crisis, thereby, adding value to the firm. Hence, Monitoring Argument suggests a positive relationship between ownership concentration and firm performance.

\subsubsection{Agency Problem}

Large corporations are generally governed by the Board of Directors, but their activities are handled by the managers. It might be possible that managers' goals may not coincide with those of shareholders andthis leads to the agency problem. This problem may be severe when ownership is dispersed among many shareholders and it becomes extremely difficult to accommodate varied individual interests of the scattered shareholder composition. (Fama\& Miller 1972; Jensen \&Meckling, 1976; and John \&Senbet, 1998)

\subsubsection{Non-linear risk appetite}

Several academicians argue that a risk-averse investor accepts non-linear return to changes in risk levels. However, with a change in the ownership stake in a company, investor's risk and return change linearly [Assuming no other investment]. As a consequence, the investor becomes risk-averse and takes measures to decrease the risk. These measures might be in favour of the 
investor but may be against the interests of the firm at large. For example: early cash-out by an investor to safeguard his/her cash position might not be in interests of a drowning firm.

\subsubsection{Quick Decision Making}

According to Gang Plank theory of Chain of Command given by Henry Fayol, quicker decisions are significantly important in a crisis situation in order to adapt to the ecosystem efficiently. Untimed, wrongly timed or delayed decisions might lead to a worse crisis situation and would hurt the firms more. This is only possible if the ownership is concentrated and lesser people have to be consulted.

For example: The early detection and isolation of cases was estimated to prevent more infections than travel restrictions and contact reductions, but integrated NPIs would achieve the strongest and most rapid effect. If NPIs could have been conducted one week, two weeks, or three weeks earlier in China, cases could have been reduced by $66 \%, 86 \%$, and $95 \%$, respectively, together with significantly reducing the number of affected areas. However, if NPIs were conducted one week, two weeks, or three 3 weeks later, the number of cases could have shown a 3-fold, 7-fold, and 18- fold increase across China, respectively. (Lai \& Ruktanonchai, 2020)

\subsection{Arguments Against Ownership Concentration}

\subsubsection{Comprehensive Decision Making}

With a decision going through the entire organisational composition, it is believed to have more inputs provided by various stakeholders and people of different mindsets. With the diverse opinions and experience clubbed with the wisdom of the top management and owners, the decision would be definitely more comprehensive and thorough.

\subsubsection{Shareholder Involvement}

If views of small shareholders are accommodated, each shareholder of the firm feels motivated and involved. These stakeholders make or break the entire firm during a crisis. The firm needs to acknowledge how the smallest shareholdings are essential to complete the equity composition and diversity. It also goes a long way in ensuring that the company has improving the reputation and goodwill of the firm in the stock market and creates positive shareholder perception.

\subsubsection{Prevention of Misuse of Authority}

Concentration of ownership may lead to misuse of authority and undue influence of large shareholders on the decision-making process of the firm. This may or may not lead to a productive and transparent functionality. Shareholdings with larger holdings may exert pressure on the decision makers to make decisions in their favor which may not be in the interest of the firm at large. For example: finding loopholes in the by-laws of the organization to allow the investors to exit with the remaining cash resources of the firm to safeguard their individual cash position.

\section{EMPIRICAL LITERATURE REVIEW}

Ownership Concentration has been researched about more actively in the recent past with greater linkages to productivity, efficiency and profitability. However, these researches make way for further research around ownership concentration and suggest different factors which can be linked to understanding the relationship and behaviour of various firm-centric and performance-determining variables. 
Berle and Means (1932) is considered to be a foundational reading around ownership concentration and focused on how the separation between the ownership and control creates a conflict between the shareholders and the managers. It also talked about how concentrated ownership often leads to a conflict between the majority and the minority shareholders. It paved the way for researchers to understand and explore different ways of managing a firm's operations. Vernon (1971) covered a greater part of ownership concentration linking it to profitability but could not establish a correlation between control status and profitability. Hill and Snell (1989) studied the effects of ownership structure on productivity differences between the firms. They believed that more the ownership will be concentrated, more will be the potent support or opposition towards a strategy.

Lemmon and Lins (2003) studied the changes in the shareholder value during the East Asian financial crisis. They concluded that there is a large separation between the cash flow ownership and the control rights that arise from the use of pyramidal ownership structures and might lead to higher agency conflicts between controlling and minority shareholders. The larger the divergence between the control and the cash flow rights, the worse the performance of the company is. (Claessens and Lang, 2000)

Past research highlights the importance of corporate governance in the markets around the world. A research conducted in the independent firms of Japan concluded how the ownership concentration is positively related to returns, but not in the firms which are members of corporate groups (Keiretsu) (Prowse 1992; Eric Gedajlovic and Daniel M. Shapiro 2002). While in the paper 'Ownership Structure \& Firm Performance: Some Empirical Evidence from Spain', Gorriz and Fumas (1996) measured firm performance in terms of both productive efficiency and profitability concluding that firms with usually high ownership concentrated have the same profitability but different productivity efficiency. Another study also found a positive relationship between the ownership concentration and performance in Ukraine Privatized Enterprises. Alexander Pivovarsky (2003) found that ownership concentration by foreign companies and banks is associated with better performance than ownership concentration by domestic owners.

Mitton (2001) showed significant impact of corporate governance on firm performance using a sample of 368 firms from Indonesia, Thailand, Korea, Malaysia and Philippines.

The evidence from papers in Indian context can be found in the studies conducted by Selarka (2005) and Pant and Pattanayak (2007). Selarka (2005) examined the block holders' influence the firm value while Pant and Pattanayak (2007) observed a significant positive impact of foreign promoters on firm value.

\subsection{Research Gap}

Most of the studies undertaken so far show that there exist a direct relationship between ownership concentration and firm performance. Different studies have explored and analyzed this relationship in different manners. Despite such extensive research work, there are little evidences about the role of ownership concentration in firm performance during crisis period, especially for Indian firm. Even with best of our efforts, we couldn't find any study that explains relationship between ownership structure of Indian firms and their performance during global financial crisis. Hence, we have made an attempt to analyze the same and contribute to the existing literature on ownership concentration and firm performance. The objective of this research paper is to study the impact of ownership concentration on return, risk and risk adjusted return of Indian firms during global financial crisis. 


\section{RESEARCH DESIGN}

\subsection{Data Source and Sample Selection}

In this study we have used financial data of Indian non-financial firms. There are several reasons for this selection. Firstly, Indian corporate sector is characterized by family owned firms which largely have concentrated ownership and the large shareholders also occupy key managerial positions in these firms. Secondly, India has several hundred listed firms, so data of a large number of firms are available for analysis. Thirdly, detailed financial data of Indian firms are available due to legal requirements of compulsory filling of annual reports. Fourthly, Indian firms prepare accounts according to well-established accounting standards which is largely consistent with IFRS. This increases our confidence in the reliability of the data as well as it enables generalization of the test results for the firms operating in similar institutional setup.

Data for this study have been are extracted from Prowess IQ database maintained by the Centre for Monitoring the Indian Economy (CMIE). The final data set consists of 1, 256 nonfinancial firms from the year 2007 to 2016 making it a panel structure of 12,560 firm year observations.

\subsection{Variables of Interest}

\section{Dependent Variables}

Return: we have used Stock Return calculated as annualized natural log returns of daily stock prices.

Risk: we have used annualized standard deviation of stock returns as proxy for firm risk

Risk Adjusted Return: we have used Jensen's alpha to measure risk adjusted return.

\section{Independent Variables}

The main independent variables used in our models are Ownership Concentration and Crisis period.

Ownership Concentration (OC): Following Jacellyet al. (2010) we have used Herfindahl index to measure ownership concentration

Crisis: we have used dummy variable (DCrisis) to proxy crises period wherein 1 represents crisis period and 0 represents non-crisis period.

\subsection{Control Variables}

Apart from ownership concentration we have used the following control variables in all our models that have significant impact on firm performance. These variables along with their proxies have been produced in Table1.

Table 1 Control Variables

\begin{tabular}{|l|l|l|}
\hline Control Variables & Symbol & Calculation \\
\hline Size & Size & Ln(Total Assets) \\
\hline Age & Age & Ln (Age) \\
\hline Leverage & LEV & Debt to Equity \\
\hline Capital Expenditures & CAPEX & Capital Expenditures to Total Sales \\
\hline Market Return & Rm & $\begin{array}{l}\text { Ln (Sensex (current value)/Sensex (previous } \\
\text { value) }\end{array}$ \\
\hline
\end{tabular}


The impact of control variables has to be controlled in the model so that we can capture the true relationship between the degree of ownership concentration and firm performance.

\subsection{Descriptive Statistics}

We have produced descriptive statistics of these variables in table 2.

Table 2 Descriptive Statistics

\begin{tabular}{|c|c|c|c|c|}
\hline Variables & Mean & Min & Max & SD \\
\hline Stock Return (Return) & 0.399 & -3.3435 & 4.2092 & 0.6301 \\
\hline Stock-SD (Risk) & 0.5366 & 0.0198 & 1.8465 & 0.1556 \\
\hline Jensen Alpha (Risk-Adj Return) & -0.0023 & -3.2911 & 3.0518 & 0.5599 \\
\hline OC & 0.6461 & 0.1400 & 0.8704 & 0.1050 \\
\hline Crisis-Dummy & 0.3 & 0 & 1 & - \\
\hline Market Return & 0.0686 & -0.4771 & 0.5592 & 0.2579 \\
\hline Age & 32.68 & 153 & 13 & - \\
\hline CAPEX & 0.0417 & -9.6895 & 1.9371 & 0.3346 \\
\hline Size & 7.7298 & 2.827 & 15.6092 & 2.0440 \\
\hline Leverage & 0.9270 & 0.0000 & 9.2900 & 1.0480 \\
\hline
\end{tabular}

The average firm in our sample has provided approximately $40 \%$ stock return with an average annual risk of 53.66\%. However, when adjusted for risk the average firm has provided a negative return during the sample period. The average ownership concentration of the firms in sample turns out be $64.61 \%$ representing very high concentration of ownership measured by hHerfindahl index. The sample firms are using debt which is equal to $92.70 \%$ of their equity value.

\subsection{Models}

We have used six fixed effect panel models to analyze the relationship between firm performance and ownership concentration along with other control variables. These models have been listed below.

Model 1: Return $_{\mathrm{it}}=\alpha+1$ OCit $+2 \mathrm{DCrisis}+3 \mathrm{CVit}+\mathrm{ui}+\mathrm{it}$

Model 2: Return $n_{\mathrm{it}}=\alpha+4 \mathrm{OCit}+5 \mathrm{DCrisis}+6 \mathrm{DCrisis} * \mathrm{OC}+7 \mathrm{CVit}+\mathrm{ui}+\mathrm{it}$

Model 3: Risk $_{\mathrm{it}}=\alpha+8 \mathrm{OCit}+9 \mathrm{DCrisis}+10 \mathrm{CVit}+\mathrm{ui}+\mathrm{it}$

Model 4: Risk $_{\mathrm{it}}=\alpha+11$ OCit $+12 \mathrm{DCrisis}+13 \mathrm{DCrisis} * \mathrm{OC}+14 \mathrm{CVit}+\mathrm{ui}+\mathrm{it}$

Model 5: Risk Adj Return it $^{=} \alpha+15$ OCit +15 DCrisis $+16 \mathrm{CVit}+\mathrm{ui}+\mathrm{it}$

Model 6: Risk Adj Return ${ }_{i t}=\alpha+17$ OCit+18DCrisis+19DCrisis*OC+20CVit + ui $+i t$

Where,

Return $_{i t} \quad=$ Stock Return, where $\mathrm{i}=\mathrm{i}^{\text {th }}$ Firm and $\mathrm{t}=\mathrm{t}^{\text {th }}$ Year.

Risk $_{\mathrm{it}} \quad=$ Annualized Standard Deviation of Stock Return, where $\mathrm{i}=\mathrm{i}^{\mathrm{th}}$ Firm and $\mathrm{t}=\mathrm{t}^{\text {th }}$ Year.

Risk-Adj $\quad=$ Jensen Alpha, where $\mathrm{i}=\mathrm{i}^{\text {th }}$ Firm and $\mathrm{t}=\mathrm{t}^{\text {th }}$ Year.

Return

$\mathrm{OC}_{\mathrm{it}}$

$=$ Ownership Centration, where $\mathrm{i}=\mathrm{i}^{\text {th }}$ Firm and $\mathrm{t}=\mathrm{t}^{\text {th }}$ Year.

DCrisis $\quad=$ Dummy Variable for Crisis, Where 1 for Crisis Period

$\mathrm{CV}_{\text {it }} \quad=$ Control Variables; Size, Leverage, Age, CAPEX, and RM where $\mathrm{i}=\mathrm{i}^{\text {th }}$ Firm and $\mathrm{t}=\mathrm{t}^{\text {th }}$ Year 
A

$\mathrm{u}_{\mathrm{i}}$

$\varepsilon_{\text {it }}$
$=$ Intercept (Constant).

$=$ Fixed parameter for each firm.

$=$ Error term, where $\mathrm{i}=\mathrm{i}^{\text {th }}$ Firm and $\mathrm{t}=\mathrm{t}^{\text {th }}$ Year.

\section{EMPIRICAL RESULTS AND DISCUSSION}

Analysis of Breusch and Pagan Lagrangian Multiplier test and Hausman test suggest that Fixed Effect panel regression model is appropriate for our data analysis. Further, we have used robust standard errors to take care of violation of assumptions of regression analysis. The results of the data analysis used to examine the impact of Ownership concentration on firm performance have been presented in Table 3 below.

Table 3 Empirical results

\begin{tabular}{|c|c|c|c|c|c|c|}
\hline & \multicolumn{2}{|c|}{ Stock Return } & \multicolumn{2}{c|}{ Risk } & \multicolumn{2}{c|}{$\begin{array}{c}\text { Risk-Adj Return } \\
\text { (Jensen's Alpha) }\end{array}$} \\
\hline & Model 1 & Model 2 & Model 3 & Model 4 & Model 5 & Model 6 \\
\hline OC & $0.982^{*}$ & $0.730^{*}$ & $-0.0994^{*}$ & $-0.074^{* * *}$ & $1.048^{*}$ & $0.859^{*}$ \\
\hline D-Crisis & $-0.143^{*}$ & $-0.349^{*}$ & $0.129^{*}$ & $0.150^{*}$ & $-0.163^{*}$ & $-0.318^{*}$ \\
\hline D-Crisis*OC & & $0.603^{*}$ & & $-0.060^{* * *}$ & & $0.454^{*}$ \\
\hline Rm & $1.203^{*}$ & $1.206^{*}$ & $0.0224^{*}$ & $0.0226^{*}$ & $0.917^{*}$ & $0.920^{*}$ \\
\hline SIZE & $-0.108^{*}$ & $-0.113^{*}$ & $-0.0212^{*}$ & $-0.0206^{*}$ & $-0.102^{*}$ & $-0.105^{*}$ \\
\hline AGE & $0.497^{*}$ & $0.550^{*}$ & $0.162^{*}$ & $0.157^{*}$ & $0.409^{*}$ & $0.449^{*}$ \\
\hline LEV & $-0.024^{* *}$ & $-0.025^{* *}$ & $0.0056^{* *}$ & $0.0056^{* *}$ & $-0.023^{* *}$ & $-0.023^{* *}$ \\
\hline CAPEX & 0.0391 & $0.0430^{* * *}$ & $-0.0188^{* *}$ & $-0.0192^{* *}$ & 0.034 & 0.037 \\
\hline C & $-1.148^{*}$ & $-1.200^{*}$ & $0.165^{* *}$ & $0.168^{* *}$ & $-0.971 *$ & $-1.010^{*}$ \\
\hline Model & FE & FE & FE & FE & FE & FE \\
\hline Error & Robust & Robust & Robust & Robust & Robust & Robust \\
\hline F-Stat & 321.20 & 288.91 & 178.93 & 159.94 & 241.62 & 212.93 \\
\hline Adj. R-S ${ }^{2}$ & 0.347 & 0.349 & 0.177 & 0.178 & 0.259 & 0.261 \\
\hline$* \mathrm{p}<0.1, * * \mathrm{p}<0.05, * * * \mathrm{p}<0.01$ & & & & \\
\hline
\end{tabular}

Saleh et al.(2017) in their empirical analysis of Australian listed firms and Alimehmeti and Paletta(2012) in their empirical analysis of Italian listed firms concluded that concentration of ownership is positively and significantly related to firm performance measured by ROA and ROE. After controlling for the control variables, our results are also consistent with these findings. Our empirical results suggest that the higher concentration of ownership has positive and significant impact on market returns of the stock but crisis period negatively affects these returns (Model 1). However, when we look at the positive sign of the coefficient of the interaction term (model 2) we conclude that those firm that have higher degree of ownership concentration perform better in the crisis period.

Since the owners of family owned businesses invest large amount of capital, they are generally risk averse. The negative and significant coefficient of risk in our models (Model 3 and Model 4) also approves the same point of view. Our results show that ownership concentration has significant and negative impact on the risk of the firm (significant at 10\% 
level) (Model 3). However, when the interaction term for ownership concentration and crisis is introduced in the model (Model 4), we find a stronger significant and negative impact of ownership concentration on firm risk (significant at $1 \%$ level). These results show that the firms with greater ownership concentration assume lower risk and they are able to keep it significantly lower during the crisis period. During the global financial crisis period these firms are able to exercise better control over risk and are able to adapt to the conditions better. Such relationship between risk and ownership concentration was also observed in empirical study by Saleh et al.(2017).

The risk adjusted returns, measured by Jensen's Alpha, also tells the similar story (Model 5). Ownership concentration has positive impact on risk adjusted returns while global financial crisis negatively affected the risk adjusted return of the sample firms. When interaction term between ownership concentration and crisis is introduced in the model (Model 6) we again observed significant positive impact of ownership concentration on risk adjusted returns.

Therefore, we finally conclude that during global financial crisis, those Indian firms which had greater degree of ownership concentration performed better. Our findings support our main proposition that ownership concentration is very significant factor affecting firm's performance, especially during crisis period. These results conform to the prior agency theory studies (Jensen and Meckling, 1976 and Anderson et al., 2003).

\section{CONCLUSIONS AND POLICY IMPLICATIONS}

A lot is still to be answered to demystify the effect of ownership concentration on the firms' performance. The present study is a humble step towards it. We applied fixed panel data analysis with robust standard errors on a large dataset of 1,256 Indian firms listed in BSE. We conclude that the firms with concentrated ownership create significant value for their shareholders reflected by positive and significant coefficient of ownership concentration with both return and risk adjusted return and negative significant coefficient of risk in our models. This relationship was observed to be stronger during the period of global financial crisis.

During this crisis period the supply of funds for new investment was badly hit Ivashina and Scharfstein (2009). American, European and Asian firms sold more assets to continue their operations and majority of the financially constrained firms either postponed or cancelled their planned investments Campello et al. (2010). So during crisis period the key to success is taking decision quickly and effectively implementing them. The firms with high ownership concentration are either governed by the owners or the owners have greater influence on the decision making and implementation process. Our results clearly suggest that such firms are able to create more value than the firms with dispersed shareholdings.

One key take away from this study is that the investors can reduce their risk on funds invested by including shares of such firms in their portfolio. The findings help investors, both big and small, and other stakeholders of the financial ecosystem to decide the kind shares to invest when a crisis is foreseen or is ongoing.

This paper contributes to the existing literature on ownership concentration and firm value taking the case of Indian firms which operate is the largest economy of South Asia. Since India is also a developing country and the ownership structure of businesses in other South Asian and South East Asian countries are similar to India, our findings can be easily are generalized for these firms operating in these countries. 


\section{REFERENCES}

[1] Alimehmeti, G., \&Paletta, A. (2012). Ownership concentration and effects over firm performance: Evidences from Italy. European Scientific Journal, 8(22).

[2] Anderson, R. C., Mansi, S. A., \&Reeb, D. M. (2003). Founding family ownership and the agency cost of debt. Journal of Financial economics, 68(2), 263-285.

[3] Berle, A. and Means, G. (1932) The Modern Corporation and Private Property. Commerce Clearing House, New York.

[4] Campello, M., Graham, J. R., \& Harvey, C. R. (2010). The real effects of financial constraints: Evidence from a financial crisis. Journal of financial Economics, 97(3), 470-487.

[5] Céspedes, J., González, M., \& Molina, C. A. (2010). Ownership and capital structure in Latin America. Journal of business research, 63(3), 248-254.

[6] Claessens, S. (2006). Corporate Governance and Development. The World Bank Research Observer, 21(1), 91-122. https://doi.org/10.1093/wbro/lkj004

[7] Claessens, S., Djankov, S., \& Lang, L. H. (2000). The separation of ownership and control in East Asian corporations. Journal of financial Economics, 58(1-2), 81-112.

[8] Edgerton, J. (2012). Agency Problems in Public Firms: Evidence from Corporate Jets in Leveraged Buyouts. Journal of Finance, 67(6), 2187-2213.

[9] Fama, E. F., \& Miller, M. H. (1972). The theory of finance. Holt Rinehart \& Winston.

[10] Gedajlovic, E., \& Shapiro, D. M. (2002). Ownership structure and firm profitability in Japan. Academy of management journal, 45(3), 565-575.

[11] Gedajlovic, E., \& Shapiro, D. M. (2002). Ownership structure and firm profitability in Japan. Academy of management journal, 45(3), 565-575.

[12] Górriz, C. G., \&Fumás, V. S. (1996). Ownership structure and firm performance: Some empirical evidence from Spain. Managerial and Decision Economics, 17(6), 575-586.

[13] Grossman, S. J., \& Hart, O. D. (1982). Corporate financial structure and managerial incentives. In The economics of information and uncertainty (pp. 107-140). University of Chicago Press.

[14] Grossman, S. J., \& Hart, O. D. (1986). The Costs and Benefits of Ownership: A Theory of Vertical and Lateral Integration. Journal of Political Economy, 94(4), 691-719.

[15] Hill, C. W., \& Snell, S. A. (1989). Effects of ownership structure and control on corporate productivity. Academy of Management journal, 32(1), 25-46.

[16] Huddart, S. (1993). The Effect of a Large Shareholder on Corporate Value. Management Science, 39(11), 1407-1421.

[17] Ivashina, V., \&Scharfstein, D. (2010). Loan syndication and credit cycles. American Economic Review, 100(2), 57-61.

[18] Jensen, M. C., \&Meckling, W. H. (1976). Theory of the firm: Managerial behavior, agency costs and ownership structure. Journal of financial economics, 3(4), 305-360. 
[19] Lemmon, M. L., \&Lins, K. V. (2003). Ownership structure, corporate governance, and firm value: Evidence from the East Asian financial crisis. The journal of finance, 58(4), 1445-1468.

[20] Leung, S., \&Horwitz, B. (2010). Corporate governance and firm value during a financial crisis. Review of Quantitative Finance and Accounting, 34(4), 459-481.

[21] Mitton, T. (2001). A Cross-firm analysis of Corporate governance on East-asian Crisis. Journal of Financial Economics, 64(2), 215-241.

[22] Pant, M., \&Pattanayak, M. (2007). Insider ownership and firm value: Evidence from Indian corporate sector. Economic and Political Weekly, 1459-1467.

[23] Pivovarsky, A. (2003). Ownership concentration and performance in Ukraine's privatized enterprises. IMF Staff Papers, 50(1), 10-42.

[24] Prowse, S. D. (1992). The structure of corporate ownership in Japan. The Journal of Finance, 47(3), 1121-1140.

[25] Salancik, G. R., \&Pfeffer, J. (1980). Effects of Ownership and Performance on Executive Tenure in U.S. Corporations. Academy of Management Journal, 23(4), 653-664.

[26] Saleh, A. S., Halili, E., Zeitun, R., \&Salim, R. (2017). Global financial crisis, ownership structure and firm financial performance: An examination of listed firms in Australia. Studies in Economics and Finance, 34(4), 447-465.

[27] Salim, R. A. (2005). Modelling entrepreneurship in small-scale enterprises. Applied Economics Letters, 12(1), 51-57.

[28] Selarka, E. (2005). Ownership concentration and firm value: A study from the Indian corporate sector. Emerging Markets Finance and Trade, 41(6), 83-108.

[29] Shleifer, A., \&Vishny, R. W. (1986). Large Shareholders and Corporate Control Author ( s ): Andrei Shleifer and Robert W . Vishny Published by: The University of Chicago Press Stable Large Shareholders and Corporate Control. 94(3), 461-488.

[30] Shleifer, A., \&Vishny, R. W. (2007). A survey of corporate governance. Corporate Governance and Corporate Finance: A European Perspective, LII(2), 52-90. 